\title{
Synthesis and Characterization of Ecofriendly and Biodegradable Soy Protein Isolate Film
}

\author{
C. Singh ${ }^{1}$, P. Sharma ${ }^{2}$ A. Bagaria ${ }^{1, *}$ \\ ${ }^{1}$ Department of Physics, Manipal University Jaipur, Jaipur, 303007, Rajasthan, India \\ ${ }^{2}$ Department of Physics, University of Rajasthan, Jaipur, 302004, Rajasthan, India
}

(Received 10 January 2021; revised manuscript received 25 March 2021; published online 09 April 2021)

\begin{abstract}
In the current study, biocompatible and biodegradable soy protein isolate (SPI) based film was developed by incorporating polar components using casting technique. The effects of additive components (glycerol, sorbitol and polyethylene glycol) with SPI were analyzed by scanning electron microscopy (SEM), Fourier transform infrared spectroscopy (FTIR) and X-ray diffraction (XRD). The result confirmed that the incorporation of polar components with soy protein isolate exhibits strong intermolecular interaction. This is the easiest method to develop biocompatible films that have wide applications in biomedical, biotechnology, food safety and food packaging industries.
\end{abstract}

Keywords: Isolated soy protein, Plasticizer, Natural polymers, Biocomposites.

DOI: 10.21272/jnep.13(2).02014

PACS numbers: 87.85.jf, 61.41. + e

\section{INTRODUCTION}

In recent scenario, there is an increasing demand for well disposable materials that are biodegradable and can supplant oil based manufactured polymers. Nondegradability and naturally unsafe nature of plastics and a few composites are the fundamental issues to be answered while addressing the environment pollution. Lot of studies have been directed on exploring materials that could prevent environmental pollution and are ecofriendly biodegradable. Proteins (polymers) have wide applications in many fields, owing to a wide range of potential functional properties as a biodegradable membrane through the formation of numerous intermolecular bonds due to the presence of polar functional groups. This makes proteins a potential film-forming candidate and the additive polar compounds could be a good alternative for increasing the functional properties of protein films. Soy protein isolate (SPI) is a biodegradable plant protein option that not only plays an important role in the conventional food, wellness and health care sector, but also offers wider application opportunities for innovative technologies, including non-formaldehyde wood adhesives, biodegradable composites and food packaging materials applications. [1-6]. A lot of research has been carried out to develop nanocomposites that could enhance the mechanical strength and other proportion of SPI [7-10]. Soy protein saps have been utilized to create green composites for some applications, for example, hydrogels, glues, plastics, film, coatings and emulsifiers, and it has likewise been accounted for as a promising material for biotechnological and biomedical use. Herein, we have introduced certain polar components in SPI for the soy film formation.

\section{MATERIALS AND REAGENTS}

Soy protein isolate (SPI) was purchased from Nutrimed healthcare, Gurugram (India), glycerol, sorbitol and polyethylene glycol (PEG400) were purchased from Molychem (India) and all chemicals in liquid form. All chemicals were used of analytical grade.

\section{PREPARATION OF SOY PROTEIN FILM}

The soy protein film (SPF) was prepared by casting method. $5 \mathrm{~g}$ SPI was mixed with $100 \mathrm{ml}$ DI water. This mixture was heated under magnetic stirring for $30 \mathrm{~min}$ at $60^{\circ} \mathrm{C} .10 \mathrm{ml}$ glycerol, $10 \mathrm{ml}$ sorbitol and $10 \mathrm{ml}$ PEG400 were then added and this mixture was kept on magnetic stirrer again for another $30 \mathrm{~min}$ at $60^{\circ} \mathrm{C}$. The final mixture was then plated on Petri plates and dried at room temperature. After drying, SPI casting films were peeled for further analysis.

\section{RESULTS AND DISCUSSION}

Fig. 1 shows the XRD analysis of SPF prepared by casting. It was seen that the SPF sample contains a peak at $2 \theta=19.86^{\circ}$. From the analysis of XRD, we observed that SPF shows amorphous structure as compared to SPI (soy protein isolate) and high intensity of XRD peak indicates a higher degree of structure that is inherent to soy protein-plasticizer interactions.

Fig. 2 shows SEM analysis of isolated soy protein film. The SPF presented a homogeneous surface incorporating glycerol, polyethylene glycol (PEG400) and sorbitol. The SEM image shows continuous and crosssection compact image of SPF due to the addition of plasticizers.

ATR FTIR is a promising technique to confirm the presence of the functional groups in the soy protein film. The ATR FTIR spectra of SP film (Fig. 3) shows absorption peak at $3289.62 \mathrm{~cm}^{-1}$ that could be referred to N-H stretching [11]. The peak at $2932.71 \mathrm{~cm}^{-1}$ was due to the $-\mathrm{CH}_{2}$ groups stretching vibrations. The data indicated that peaks of amide $\mathrm{I}(\mathrm{C}=\mathrm{O}$ stretching $)$, amide II (N-H bending), and amide III $(\mathrm{C}-\mathrm{N}$ and $\mathrm{N}-\mathrm{H}$ stretching) at $1643.39,1543.56$, and $1236.64 \mathrm{~cm}^{-1}$, respectively. The peak at $1414.44 \mathrm{~cm}^{-1}$ showed vibrational stretching of $\mathrm{C}=\mathrm{C}$ bonds. The spectrum showed absorption bands around at $1076.79 \mathrm{~cm}^{-1}$ and $1032.97 \mathrm{~cm}^{-1}$ attributed to the $\mathrm{C}-\mathrm{O}$ stretching vibrations owing to the glycerol. The peak at $925.31 \mathrm{~cm}^{-1}$ was owing to the vibration bend of $\mathrm{C}-\mathrm{H}$ [12-16].

\footnotetext{
* ashima.bagaria@jaipur.manipal.edu

The results were presented at the International Conference on Multifunctional Nanomaterials (ICMN2020)
} 


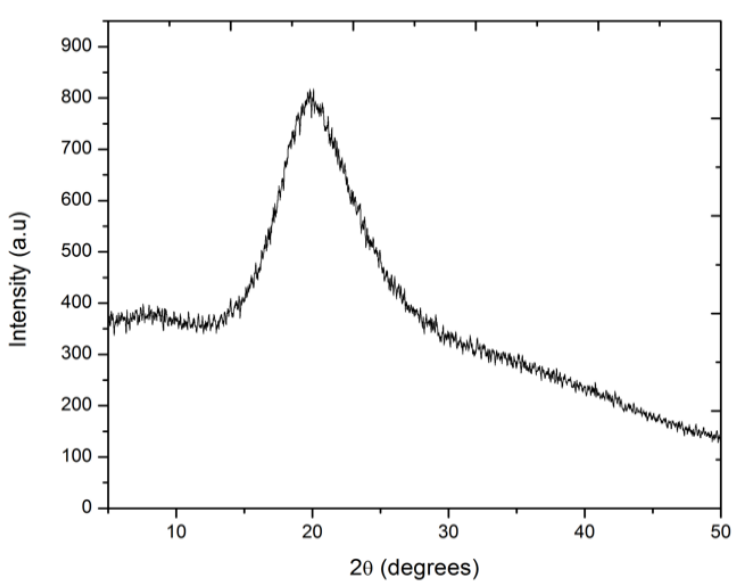

Fig. 1 - XRD pattern of SP film

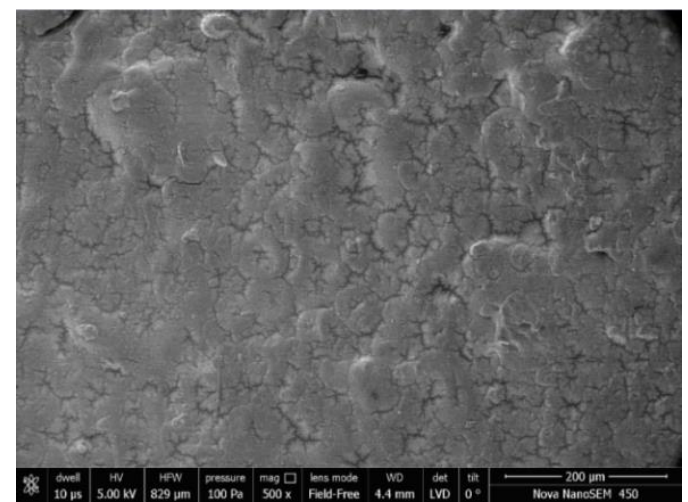

Fig. 2 - SEM image of SP film

\section{REFERENCES}

1. A.H. Brandenburg, C.L. Weller, R.F. Testin, J. Food Sci. $\mathbf{5 8}$, 1086 (1993).

2. L.T. Lim, R. Chan, S. Barbut, M.F. Marcone, Polymer Proc. 29 No 4 (2014).

3. W.G. Cochran, G.M. Cox (John Wiley \& Sons, Inc.: New York: 1957).

4. N. Gontard, S. Guilbert, (Blackie Academic \& Professional: London: 1994).

5. J.M. Krochta, C.D. Mulder-Johnston, Food Technol. 51, 61 (1997).

6. T.H. McHugh, J.M. Krochta, J. Agric. Food Chem 42, 841 (1994).

7. M.B. Pérez-Gago, P. Nadaud, J.M. Krochta, J. Food Sci 64 , 1034 (1999).

8. H. Pol, P. Dawson, J. Actton, A. Ogale, J. Food Sci. 67, 212 (2002).

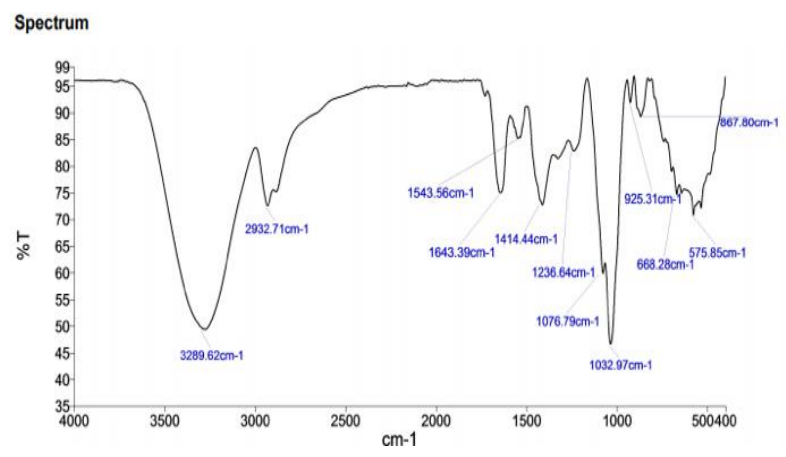

Fig. 3 - FTIR spectra of SP film

\section{CONCLUSIONS}

Protein based films are fragile. The functional properties of films based on isolated soy protein can be improved by incorporation of additive polar components which were confirmed by characterization. Additive polar components are useful to reduce the brittleness of SP film and turn it into useful biomaterials. This sample preparation method gives more attention to simple synthesis as compared with other complex protocols.

\section{ACKNOWLEDGEMENTS}

The authors greatly acknowledge MRC division of MNIT (Jaipur), Central University of Rajasthan (CURAJ) Jaipur for their help in sample characterization (XRD, SEM and FTIR). Chandan Singh acknowledges Department of Physics Manipal University Jaipur for constant support and encouragement.

9. J.W. Rhim, A. Gennadios, A. Handa, C.L. Weller, M.A. Hanna, J. Agric. Food Chem. 48, 4937 (2000).

10. S.F. Sabato, B. Ouattara, H. Yu, G. D'Aprano, C. Le Tien, M.A. Mateescu, M. Lacroix, J. Agric. Food Chem. 49, 1397 (2001).

11. B.H. Luo, Ch.-En Hsu, J.-H. Li, L.-F. Zhao, M.-X. Liu, X. Y. Wang, Ch.-R. Zhou, J. Biomed. Nanotechnol. 9, 649 (2013).

12. Z. Luo, J. Mater. Chem. 2, 7327 (2014).

13. W. Xu, J. Appl. Polym. Sci. 132, 41451 (2014).

14. H. Kang, Z. Wang, W. Zhang, Food Hydrocolloids 61, 923 (2016).

15. C. Xia, La Wang, Y. Dong, Sh. Zhang, Sh.Q. Shi, L. Caib, J. Li, RSC Adv. 5, 82765 (2015).

16. D. Liu, X. Sun, H. Tian, S. Maiti, Z. Ma, Cellulose 20, 2981 (2013).

\title{
Синтез та характеристика екологічно чистої та схильної до біологічного розкладання плівки ізоляту соєвого білка
}

\author{
C. Singh ${ }^{1}$, P. Sharma ${ }^{2}$, A. Bagaria ${ }^{1}$
}

${ }^{1}$ Department of Physics, Manipal University Jaipur, Jaipur, 303007, Rajasthan, India

2 Department of Physics, University of Rajasthan, Jaipur, 302004, Rajasthan, India

У дослідженні біосумісна та схильна до біологічного розкладання плівка ізоляту соєвого білка (SPI) була розроблена шляхом включення полярних компонентів за допомогою техніки лиття. Вплив додаткових компонентів (гліцерин, сорбітол та поліетиленгліколь) з SPI аналізували за допомогою 
скануючої електронної мікроскопії (SEM), інфрачервоної спектроскопії з перетворенням Фур'є (FTIR) та рентгенівської дифракції (XRD). Результат підтвердив, що включення полярних компонентів з ізолятом соєвого білка демонструє сильну міжмолекулярну взаємодію. Це найпростіший метод розробки біосумісних плівок, які мають широке застосування в біомедицині, біотехнології, безпеці харчових продуктів та промисловості їх пакування.

Ключові слова: Ізольований соєвий білок, Пом'якшувач, Природні полімери, Біокомпозити. 